\title{
Trends in Deforestation as a Response to Management Regimes and Policy Intervention in the Hindu Kush Himalaya of Pakistan
}

\author{
Adnan Ahmad ${ }^{1,2 \dagger}$, Shahid Ahmad ${ }^{1,3,4 \dagger}$, Ghulam Nabi ${ }^{3,4}$, Qi-Jing Liu ${ }^{1}$, Nazirul Islam ${ }^{5}$ and \\ Xiaofeng Luan ${ }^{1 *}$ \\ ${ }^{1}$ College of Forestry, Beijing Forestry University, Beijing, China, ${ }^{2}$ Department of Forestry, Shaheed Benazir Bhutto University, \\ Sheringal, Pakistan, ${ }^{3}$ Key Laboratory of Molecular Biology and Cellular Biology, College of Life Sciences, Ministry of Education, \\ Hebei Normal University, Shijiazhuang, China, ${ }^{4}$ Key Laboratory of Animal Physiology, Biochemistry and Molecular Biology of \\ Hebei Province, College of Life Sciences, Ministry of Education, Hebei Normal University, Shijiazhuang, China, ${ }^{5}$ School of \\ Sciences and Resources, Changan University, Xian, China
}

\section{OPEN ACCESS}

Edited by:

Jonah Henri Ratsimbazafy,

Madagascar Primate Study and

Research Group, Madagascar

Reviewed by:

Wasim Sajjad,

National University of Medical

Sciences (NUMS), Pakistan

Anam Ashraf,

Tsinghua University, China

${ }^{*}$ Correspondence:

Xiaofeng Luan

luanxiaofeng@bjfu.edu.cn

${ }^{+}$These authors have contributed equally to this work and share first authorship

Specialty section: This article was submitted to Conservation and Restoration Ecology,

a section of the journa Frontiers in Environmental Science

Received: 07 November 2021 Accepted: 03 February 2022

Published: 02 March 2022

Citation:

Ahmad A, Ahmad S, Nabi G, Liu Q-J Islam N and Luan X (2022) Trends in Deforestation as a Response to Management Regimes and Policy Intervention in the Hindu Kush Himalaya of Pakistan.

Front. Environ. Sci. 10:810806. doi: 10.3389/fenvs.2022.810806
Based on the annual rate of deforestation as a forest conservation outcome, this study evaluated how effective is the existing forest management regime in controlling deforestation in the study area. Remote sensing data were used to measure the rate of deforestation. Furthermore, the existing forest management regime in the study area, as well as in other regions of the Himalayan and Karakoram ranges of Pakistan and the Himalayan temperate biome of India, China, Nepal, and Bhutan, was reviewed to compare deforestation. The results showed that, with regional-wise management regimes, the overall annual rate of deforestation was recorded much higher in the study area $\left(0.8 \mathrm{yr}^{-1}\right)$ compared to the Himalayan and Karakoram ranges of Azad Kashmir $\left(0.13 \% \mathrm{yr}^{-1}\right)$, Punjab $\left(0.20 \% \mathrm{yr}^{-1}\right)$, and Gilgit Baltistan $\left(0.31 \% \mathrm{yr}^{-1}\right)$. The cross-national and site-regional findings highlighted that lowest deforestation was associated with management regimes characterized by effective monitoring and law enforcement with the inclusion of conservation and community. Deforestation was higher in forest management regimes that aimed to maximize economic growth, unstable rights, weak law enforcement, and exclusion of conservation and community-based management/use. In conclusion, the best forest conservation outcomes are associated with management regimes that include conservation and community and stable and secure rights supported by high-ranking monitoring and law enforcement. Therefore, the inclusion of community and conservation supplemented with stable rights and high-rank monitoring and law enforcement into the existing management regimes is suggested.

Keywords: forest management, ban policies, deforestation, conservation outcomes, Himalaya

\section{INTRODUCTION}

Forest carbon management and conservation are globally recognized as a potentially low-cost choice for climate change mitigation, with supplementary benefits for biodiversity, regulating the hydrological cycle and other multiple ecosystem services (Canadell and Raupach, 2008; DeFries et al., 2010). The United Nations Framework Convention on Climate Change (UNFCCC) considers 
emission reduction from controlling deforestation and forest degradation as a cost-effective strategy (DeFries et al., 2010). Such strategies will be effective in controlling deforestation only if they address the causes that promote deforestation such as underlying and controlling drivers. Deforestation has direct drivers (agriculture and settlement expansion), underlying drivers which include population growth and policies, and controlling factors such as urban expansion, local and cultural attitudes toward forests, and the scale of incentives for forest conservation (Keenan et al., 2015). Understanding the drivers of deforestation and their monitoring is fundamental for developing policies that aim to change the current trends in forest management toward more climate-friendly and carbondiversity-friendly outcomes (Hosonuma et al., 2012; Ahmad et al., 2018).

Deforestation in developing countries has attached greater importance to policymakers in the last two decades. To control the rate of deforestation, numerous conservation strategies such as logging bans and regulations, payments for ecosystem services, and establishment of protected areas have been implemented worldwide (Angelsen, 2010; Angelsen et al., 2012). Prohibitions on logging (partial or full ban) as a conservation tool have been implemented in many countries like India, Pakistan, Bangladesh, Thailand, China, Indonesia, and New Zealand, to control the rate of deforestation (Brown et al., 2001; Tuynh and Phuong, 2001). The results of such measures are variable, with positive outcomes in certain countries (e.g., New Zealand, China, and Sri Lanka), while uncertain in countries like Pakistan, Bangladesh, and Thailand (Zeb, 2019). Similarly, in general, establishing the protected areas limits the rate of deforestation in developing countries (Bugayong, 2006; Fischer and project, 2010; Sarker et al., 2011; Halim, 2011). However, the fact is that protected areas consist of a small proportion of global forests, and in forests outside protected areas, rates of deforestation are widely different among countries (Bertzky et al., 2012; Brandt et al., 2017; Hansen et al., 2013).

The forest management regimes and associated policies at the national and regional levels can have huge impacts on the rate of deforestation because they are underlying, not just direct driving forces (Lambin and Geist, 2008; Lambin and Meyfroidt, 2010). Based on the management goals, forest management aims can be set different, including economic development, sustainable use and carbon-diversity conservation, and supporting local livelihoods (Lambin and Geist, 2008). Under the implemented management regimes, the goals to be achieved are different regarding land-tenure and rights arrangements and exclusion or inclusion of conservation in management (Brandt et al., 2017). However, the success or failure of the goals of management regimes can be affected by socio-economic, cultural, political, and institutional conditions, which might also limit management effectiveness. Excessive attention has been given to these conditions as factors of deforestation corresponding to national forest management itself as a driver (Geist and Lambin, 2001; Bare et al., 2015).

Pakistan is a forest-deficit country (5\% of its geographical area under forest) and has witnessed a higher deforestation rate
(Ahmad et al., 2018). According to different estimates, the annual rate of deforestation in the country varied between 0.7 and 2\% (FAO, 2011; FAO, 2015; Qamer et al., 2016). Of the total forest land, $67 \%$ of the forest in the country exists in the hilly area of Himalayan, Hindu Kush, and Karakoram ranges. The forest resources in the Hindu Kush Himalayan ranges were declared as protected forests in 1970, where the state owned and managed the forest; however, the local communities were entitled to different rights (Qamer et al., 2016). Forest management in the study region has remained provincial responsibility mostly based on colonial laws. Under this formal legal management system, the local communities were restricted in forest management. In response to disastrous floods in 1992-1993, the government of Pakistan initiated some major reforms for the conservation and management of forests (Yusuf, 2009; Fischer and project, 2010). Such reforms include a logging ban throughout the country, a Forestry Sector Master Plan (1992), the Sarhad provincial conservation strategy (1996), Hazara Community Participation Rules (1996-97), KP forest ordinance (2002), and their Community Participation Rules, 2004 (Yusuf, 2009). The recent National Forest Policy (2015) also aims to expand protected areas (MCC, 2015). Moreover, recently, the government of Pakistan launched the "Protected Areas Initiative" program for expanding PAs from 12 to $15 \%$ (IUCN, 2020). Despite these major reforms, the current rate of deforestation in Pakistan is still much higher, which is attributed to the ineffective implementation of the abovementioned reforms (Ahmad et al., 2018; Zeb, 2019).

Deforestation and its direct drivers have been widely studied in Pakistan (Qasim et al., 2011; Qamer et al., 2016; Ahmad et al., 2018; Mannan et al., 2018). Similarly, based on the local scale, few of the studies give some insights into the ban policy and legal and institutional reforms on deforestation (Fischer and project, 2010; Yusuf, 2009; Zeb, 2019). However, the effect of the existing forest management regimes and their associated ban policies itself as a driver has not yet been evaluated, particularly in the protected forests of the Hindu Kush Himalayan ranges. As in these regions, the local communities claim ownership rights over the forests. Such rights are frequently contested between the state and local communities upon implementing reforms and policies. This study, for the first time in Pakistan, evaluated the effect of existing forest management regimes and their associated policies on the rate of deforestation. We used remote sensing data to assess the rate of deforestation in the study area. Similarly, we evaluated how cross-national management regimes across the Himalayan temperate biome (China, India, Nepal, Bhutan, and Myanmar) and site-regional management regimes in Pakistan are effective for forest conservation outcomes. We linked the difference in the rate of deforestation (as a conservation outcome) affected by management regimes focusing on the degree of decentralization and policy implementation, local political and socio-cultural scenarios, the scale of community participation in management, and the use of forests for economic growth versus sustainable management and conservation. 


\section{MATERIALS AND METHODS}

\section{Study Area}

The study was carried out in the Hindu Kush Himalayan ranges of Malakand civil division (MKD) of the Khyber Pakhtunkhwa province, Pakistan (Figures 1A,B). The total land area of the region is 2.98 million hectares and extends between $34^{\circ} 9^{\prime}$ and $36^{\circ} 55^{\prime}$ in latitude and $72^{\circ} 10^{\prime}$ and $73^{\circ} 55^{\prime}$ in longitude (KPBS, 2020). The elevation ranges from 450 to $7,782 \mathrm{~m}$. The climate is sub-tropical to temperate. The average annual minimum and maximum temperatures vary from -6 to $40^{\circ} \mathrm{C}$ (Mannan, 2009). The mean annual precipitation varies between 500 and $1,600 \mathrm{~mm}$. The forests extend over an area of 0.8 million ha (27\%). The major forest types in the area include sub-tropical broadleaved semi-evergreen forests, sub-tropical Chir forests, moist temperate forests, dry temperate forests, and sub-alpine forests. The major conifer tree species of the area include Cedrus deodara, Pinus wallichiana, Pinus gerardiana, Pinus roxburghii, Abies pindrow, Picea smithiana, Taxux baccata, and the major broadleaved species including Quercus incana, Olea ferruginea, Juglans regia, Morus alba, Betula utilis, Populus ciliata, and Acacia modesta.

\section{Assessment of the Rate of Deforestation}

The data regarding the forest cover change in the study area were obtained from the Landsat images of 2009 and 2020 from the United States Geological Survey (https://www.usgs.gov/). Two maps for the years 2009 and 2020 were scanned and processed in the processing software. The GPS (Global Positioning System) and area topographic sheet were used for geometric correction of the image. The radiometric and atmospheric corrections were performed in FLASH and radiometric calibration tools available in ENVI 5.1. For the classification of the study area into different classes such as forest, agricultural land, barren land, built area, glacier, and water bodies, the satellite data were examined, and pre-pixel signatures were assigned. Post-classification smoothing and confusion matrix ground truth were used to improve the quality of classification and image accuracy. The accuracy of the classified images was also assessed through kappa statistics. We used a supervised maximum likelihood algorithm for the spectral classification of the images. For the forest cover change detection, multi-data post-classification change detection techniques were performed (Ahmad et al., 2018; Mannan et al., 2019). The average rate of deforestation was calculated (Puyravaud, 2003).

\section{Characteristics of Forest Management Regimes and Their Conservation Outcomes}

The available database of Forestry Statistics of Pakistan as well as other documents was sourced to determine the proportion of forest area under five categories: state-owned forests, reserved forests, protected forests, Guzara forests, and communal forests in Pakistan (Khan, 2004; Yusuf, 2009; CCF, 2011; PBS, 2017). The forest management regimes in each category were evaluated. To characterize the forest management regimes in the study area, we also reviewed the management plan documents (Saddozi, 1995; Muhammad, 2000; Mannan, 2001; Mannan, 2002; Usman, 2017).
Similarly, the management regimes in the Himalayan temperate biome (China, India, Myanmar, Nepal, and Bhutan) were also reviewed for comparison (Brandt et al., 2017).

The annual rate of deforestation was our measure of forest conservation outcome under the existing forest management regimes. The annual rate of deforestation with associated management regimes in the study area was calculated from satellite images (2009-2020). For deforestation comparison concerning management regimes, the annual rate of deforestation in the Himalayan and Karakoram regions of Pakistan was sourced from Mannan et al. (2019), Qamer et al. (2016), and Qasim et al. (2011). Furthermore, to compare the annual rate of deforestation with the Himalayan temperate biome, the annual rate of deforestation in China, India, Myanmar, Nepal, and Bhutan under the respective forest management regimes was sourced from Brandt et al. (2017).

\section{RESULTS AND DISCUSSIONS}

\section{Rate of Deforestation}

The results showing the annual rate of deforestation in the region are given in Figures 2-4. Our results showed that, in 2009, forest covered an area of 381,551 ha, while it was 349,228 ha in the year 2020. Over this period (2009-2020), a substantial decrease occurred in the forest area. Overall, 32,323 ha of forests were lost and the annual rate of deforestation recorded was 2,938 ha $(0.8 \%)$. This annual rate of deforestation was much higher than the estimated rate of deforestation in the Himalayan (Murree and Islamabad, 0.13-0.20\%) and Karakoram (Gilgit, 0.31\%) ranges of Pakistan reported by Qamar et al. (2012) and Mannan et al. (2019).

\section{Categories of Forest and Characteristics of Forest Management Regimes in the Hilly Areas of Pakistan}

In the hilly area of Pakistan, there are six different categories, including state forests, reserved forests, protected forests, Guzara forests, communal forests, and private plantations. Details of the different categories of forests with respective management regimes are given in Table 1. The state forests in Pakistan are found in Azad Jammu and Kashmir (AJK). In these forests, the local communities hold the rights to grazing, grass cutting, and timber collection for house repairs. Similarly, in communities living within $4.8 \mathrm{~km}^{2}$ of the forest's boundaries, rights are granted for agriculture and domestic uses to landowners and tenant farmers; however, such concessions cannot be sold or bartered. Reserved forests are mostly found in the foothills of Himalaya in the Punjab (PUN) province and the Hazara Division of the Khyber Pakhtunkhwa (KPK) province. In the reserved forests of Punjab, rights and concessions are rare. In KPK, under KP forest ordinance 2002, rights and concessions such as grazing can be admitted by the FSB (Forest Settlement Board). However, no rights can be acquired except by succession. Similarly, no rights can be transferred by mortgage, sale, lease, or grant. 


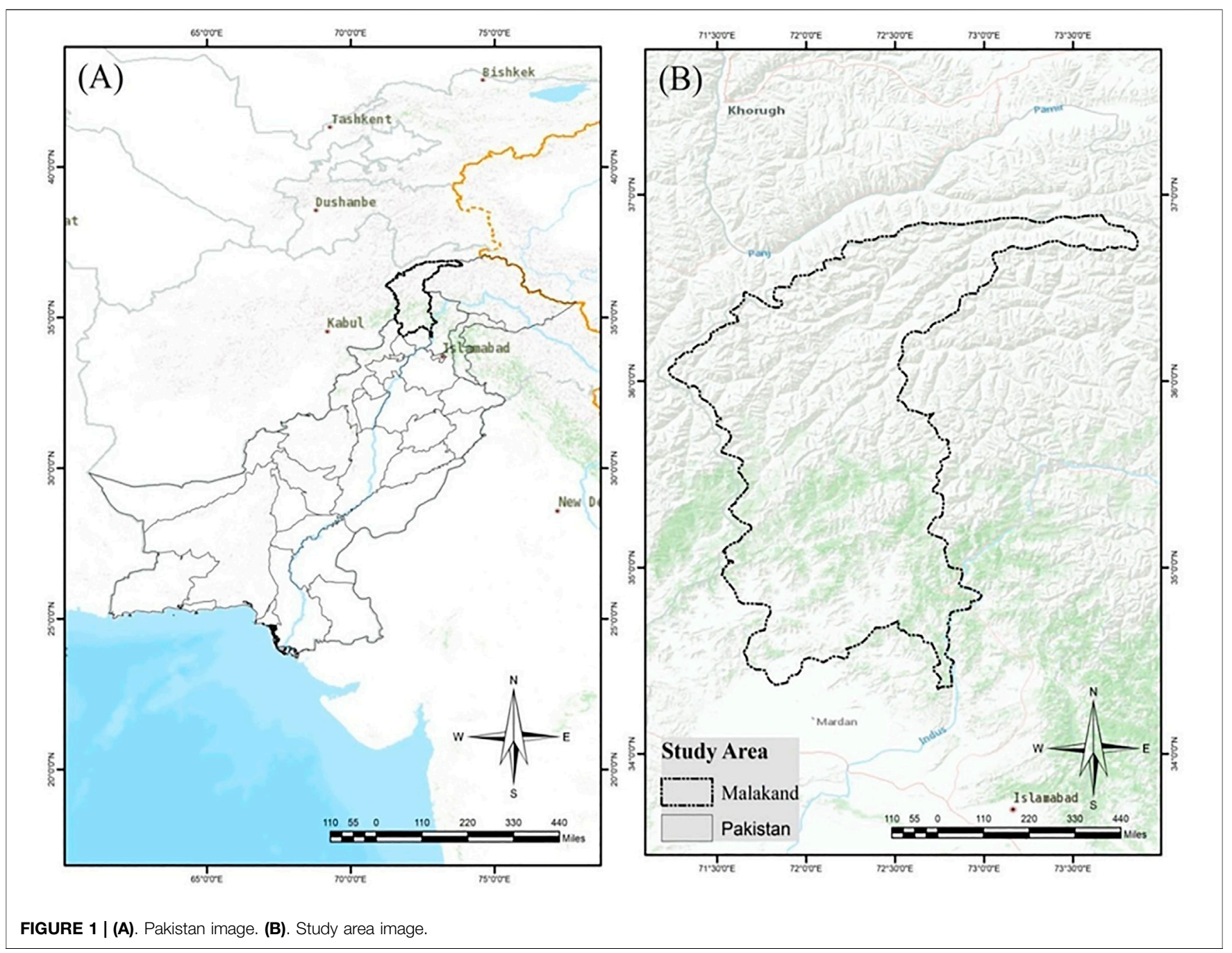

Guzara forests in the province of Punjab are located in Murree and Rawalpindi. The ownership of these forests is vested to the local community either as joint property or as individual property. Timber from the dead, dry windfall, and uprooted trees are sold through public auctions. Of the total revenue, $70 \%$ of the revenue goes to the village Guzara fund in the case of joint or communal forest property and 30\% to the central Guzara fund and staff welfare, whereas in the case of individual property, $70 \%$ of the revenue goes to the landowner and the rest goes to the central Guzara fund and staff welfare. In the KPK province, the Guzara forests are located in Haripur, Abbottabad, Kohistan, Mansehra, and Battagram of the Hazara civil division. The KPK Forest Department regulates forests in these regions. The major rights in Guzara forests include timber for domestic use, shares in a timber sale, collection of fuel wood, and fodder for livestock, grazing, and a seignorage fee. The owners can cut from 1 to 3 trees for domestic uses on a specific permit issued by the forest department; however, the tenants and the landless communities do not have the right to cut trees.

The communal forests are located in the Karakoram ranges of Gilgit Baltistan. In these forests, the land tenure system is clear.
The government respects all the property rights of the local communities and manages the forests in the best interest of owners. The tree marking and harvesting is regulated by the forest department, and the forest department obtained a fixed royalty which is based on the species type and harvested volume. Private plantations in KPK are forests on land in which the landowner has an undisputed right of ownership. The harvesting is either carried out by the owner or regulated by the forest department.

Protected forests are found in the Hindu Kush Himalayan ranges in the Malakand civil division of the KPK province (study area). These forests are inherited from the princely states of Dir, Chitral, and Swat and were declared as protected forests in the 1970s. The state owned and managed the forests, and the local people are entitled to different rights and concessions. These rights include out of commercial sale proceeds, $60-80 \%$ share, to local people as "Royalty", right of cutting dry branches and trees for firewood, right of getting timber for domestic construction, right of grazing, right of collecting non-timber forest products, and right of collecting a fee from the nomadic communities (Ahmad et al., 2018). In the study area, the management of forests also varies by sub-regions. Forests in Chitral and Swat regions are 


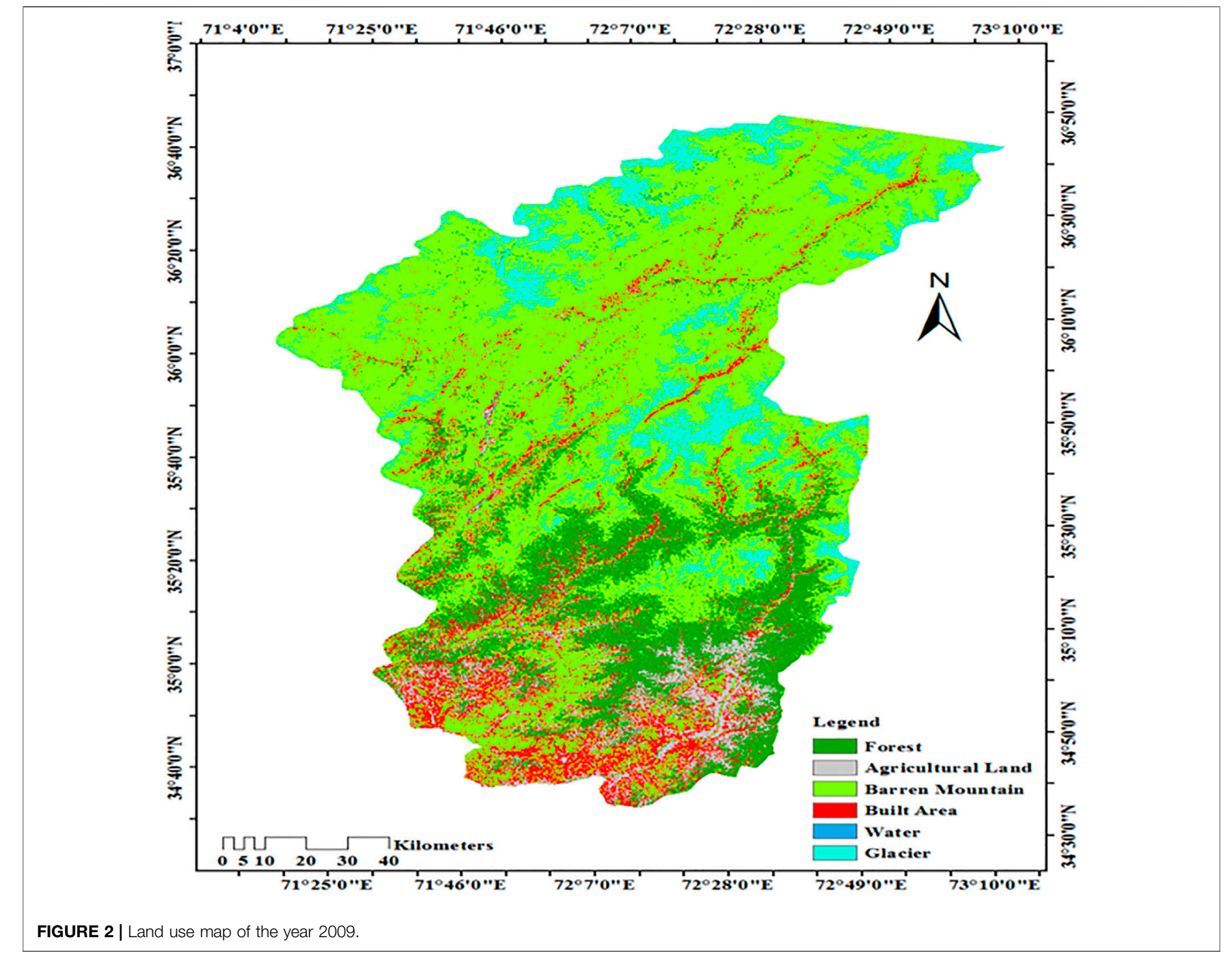

70 and $65 \%$ protected, respectively, while in the Dir region, about $40 \%$ of forests are protected forests. In Chitral and Swat regions, 28 and $35 \%$ of forests are private plantation, respectively. In the Dir region, about $16 \%$ of forests are communal, and $12 \%$ are private plantation.

\section{Differences in the Rate of Deforestation With Respect to Forest Management Regimes}

The results of differences in the rate of deforestation in different areas in Table 2 highlighted the lowest rate of deforestation in AJK (Himalayan ranges), which is $0.13 \% \mathrm{yr}^{-1}$ (Qamer et al., 2016). The highest annual rate of deforestation (0.8\%) was recorded for the Hindu Kush Himalayan ranges of Malakand civil division (Table 2). In Gilgit Baltistan (Karakoram ranges), the annual rate of deforestation was estimated at $0.31 \%$, while in Islamabad and Murree, the annual deforestation rate was recorded at 0.20\% (Qamer et al., 2016; Mannan et al., 2019). The results highlighted a substantial difference in the rate of deforestation in different regions under respective forest management regimes. The results indicated that state forests in AJK with associated management regimes have the most positive forest conservation outcomes in deforestation, followed by Murree and Islamabad. Effective monitoring and law enforcement and the inclusion of conservation and protected areas in AJK resulted in a lower deforestation rate. Similarly, in Murree and Islamabad, a better level of monitoring and enforcement and the inclusion of conservation (protected areas) and stable community rights (Guzara forests of Murree) resulted in effective conservation outcomes. Although the government admitted all the ownership rights in GB, the relatively high rate of deforestation compared to that in AJK and Murree/Islamabad might be the result of weak law enforcement and the lack of experts and technical staff (Tan, 2006).

The existing management regimes in the study area (Hindu Kush ranges of MKD) associated with weak law enforcement and policy implementation community and conservation exclusion, unstable and insecure land tenure rights, and continuous 

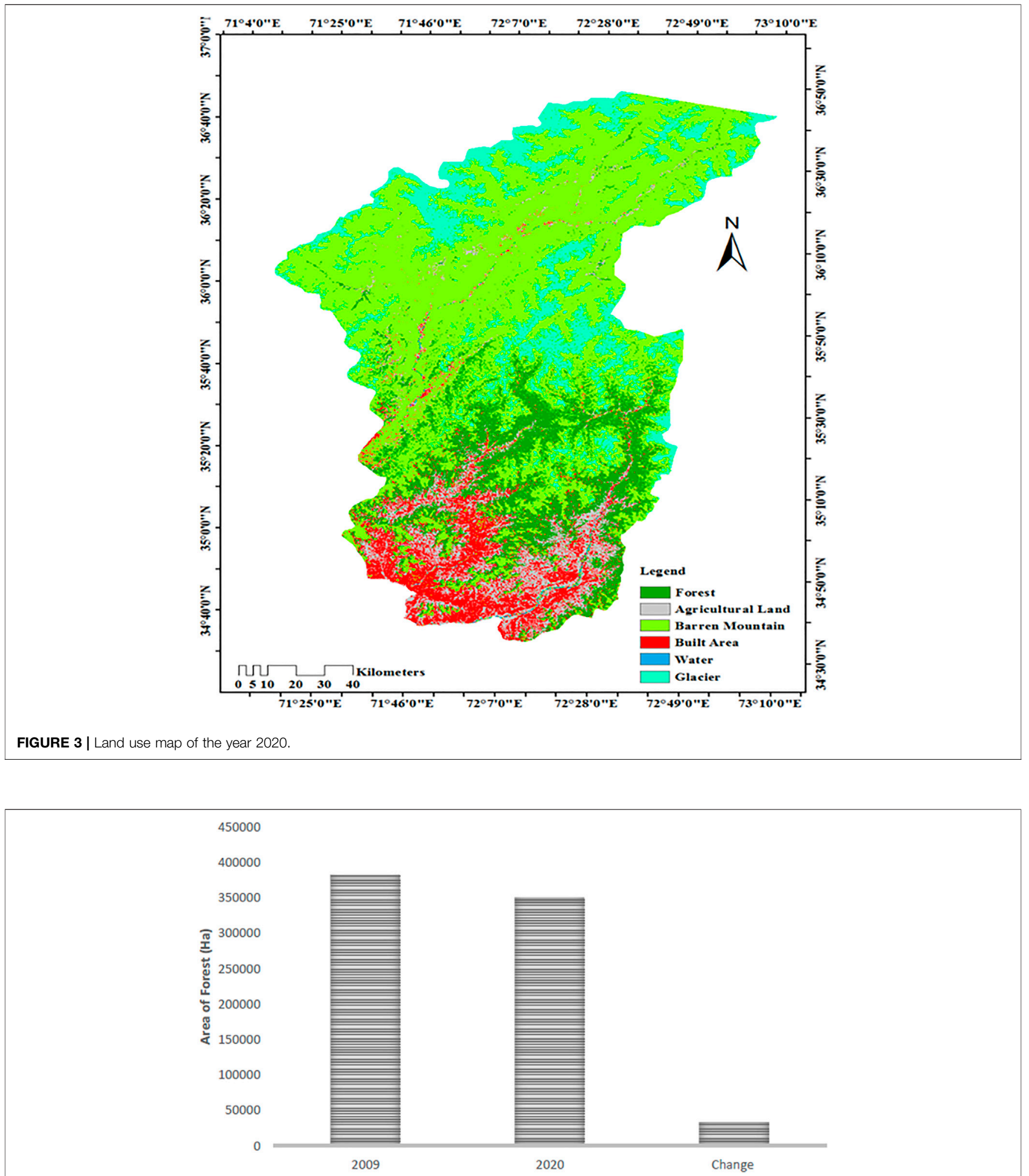

FIGURE 4 | Change in the forest area from 2009 to 2020. 
Table 1 | Categories of forests and management characteristics in the hilly areas of Pakistan (000 ha).

\begin{tabular}{|c|c|c|c|c|c|c|}
\hline Category & $\begin{array}{l}\text { Management } \\
\text { characteristics }\end{array}$ & PUN & KPK & AJK & GB & Total \\
\hline State forests & Owned and managed by government with no or limited rights to community & 000 & 000 & 567 & 000 & 567 \\
\hline Reserve forests & Owned and managed by government with limited rights to community & 324.4 & 100 & 000 & 000 & 424.4 \\
\hline Protected forests & Owned and managed by government with multiple rights to community & 224.7 & 590 & 000 & 65 & 879.7 \\
\hline Guzara forests & Owned by community managed by government & 40.3 & 261 & 000 & 000 & 301.3 \\
\hline Communal forest & Owned by community managed by government & 000 & 000 & 000 & 219.6 & 219.6 \\
\hline Private plantation & Private ownership jointly managed & 000 & 740 & - & - & 740 \\
\hline Total area & - & 589.1 & 1,691 & 567 & 284 & 3,132 \\
\hline
\end{tabular}

Source: Wani et al. (2004); Tan (2006). PUN, Punjab; KPK, Khyber Pakhtunkhwa; AJK, Azad Jammu and Kashmir; GB, Gilgit Baltistan.

TABLE 2 | Differences in the rate of deforestation in different hilly areas of Pakistan.

\begin{tabular}{lcc}
\hline Area/region & Period & $\begin{array}{c}\text { Annual } \\
\text { rate of deforestation }\end{array}$ \\
\hline Study area & & 0.8 \\
Azad Jammu and Kashmir & $2009-2020$ & 0.13 \\
Gilgit Baltistan & $1990-2010$ & 0.31 \\
Islamabad and Murree & $1990-2010$ & Qamer et al. (2016) \\
& $1998-2018$ & Qamer et al. (2016)
\end{tabular}

government's bureaucratic interference, illegal cutting are the major factors of the high rate of deforestation (Tan, 2006; Yusuf, 2009). The highest rate of deforestation in the study area may also be attributed to the logging ban policy. The rate of deforestation was recorded higher after the logging ban in 1992 as compared to that before the logging ban (Qasim et al., 2011; Zeb, 2019). Despite the logging ban, the increase rate of deforestation reflects the non-effectiveness of logging ban policy in the area under the respective management regime. The ban policy shifted the pattern of deforestation from a higher elevation to a lower elevation. This shifting pattern of deforestation during the postban period might be attributed to the closure of temperate and sub-alpine (coniferous) forests for communities' rights (Ahmad et al., 2018; Zeb, 2019). Before the ban, the local people were mostly dependent on the coniferous forests for timber and fuelwood, and oak and broadleaved semi-evergreen forests were used for livestock fodder and fuelwood. After banning, biotic pressure on the lower elevation forest zones increases in terms of grazing, fodder, fuelwood, and timber extraction. The present findings are consistent with the results of Alix-Garcia et al. (2005), Palmer and Engel (2009), Elsen et al. (2018), and Warman and Nelson (2016). They observed an increasing trend in the rate of deforestation under the logging bans and management regulations.

At sub-regions, the rate of deforestation rate varies. Swat regions have the highest rate of deforestation (1.4\%), followed by Chitral $(0.71 \%)$, while the Dir region has the lowest deforestation rate of $0.4 \%$ (Qasim et al., 2011; Qamer et al., 2012; Ahmad and Nizami, 2015; Ullah et al., 2016; Ahmad et al., 2018; Zeb, 2019). The sub-regional statistics revealed that formal and informal community forest management and rights play an important role in forest management. In Dir regions, about $16 \%$ of forests belong to local communities.
Additionally, in Dir regions, the local communities are actively involved in joint forest management (JFM), which was introduced by the KP government in 2004. In Swat regions, the absence of communal forests and inactive JFM resulted in a higher rate of deforestation. Though in Chitral communal forests are not existing, the lower rate of deforestation might be attributed to active JFM compared to Swat.

We further compare the current rate of deforestation in our study area with the rate of deforestation in China, India, Nepal, Bhutan, and Myanmar in the Himalayan temperate biome during 2000 and 2014 (Brandt et al., 2017). The characteristics of national forest management in respective countries and the rate of deforestation are given in Table 3. The table results demonstrate that countries with high conservation priorities and community-based management such as Nepal and Bhutan had lower deforestation rates than other countries. Both countries have a larger forest area protected with a high level of monitoring and law enforcement in Nepal and centralized management in Bhutan. In contrast, priorities of China, India, and Myanmar lack conservation in terms of communities' benefits. Also, Myanmar and China's forest management regimes are development and profit-oriented. Moreover, China, entitled with unstable and inconsistent rights to communities (Woods, 2015; Yang et al., 2015), and Myanmar, have insufficient monitoring mechanisms (Sikor et al., 2013).

In the study area, the current forest management regimes resemble Myanmar in terms of commercial exploitation and weak law enforcement and China in terms of unstable and inconsistent rights. The coniferous and sub-alpine forests are declared as protected forests owned and managed by the state with multiple rights and concessions to local communities. 
TABLE 3 | Characteristics of the national forest management regime and the rate of deforestation.

\begin{tabular}{|c|c|c|c|}
\hline $\begin{array}{l}\text { Country/ } \\
\text { region }\end{array}$ & $\begin{array}{l}\% \\
\text { DFR } \mathrm{yr}^{-1}\end{array}$ & $\begin{array}{l}\text { Characteristics of national } \\
\text { forest management }\end{array}$ & References \\
\hline Bhutan & 0.5 & $\begin{array}{l}\text { Centralized management (all forest is owned and managed by the state, } 46 \% \text { protected, } 52 \% \\
\text { reserve) }\end{array}$ & $\begin{array}{l}\text { Bhattarai and Hammig (2004); Brandt } \\
\text { et al. (2017) }\end{array}$ \\
\hline Nepal & 0.6 & $\begin{array}{l}\text { Government ( } 68 \% \text { forest area) and community-based management ( } 32 \% \text { forest area), with a } \\
\text { high level of monitoring and enforcement }\end{array}$ & Ojha et al. (2009); Brandt et al. (2017) \\
\hline China & 1.3 & $\begin{array}{l}\text { Government managed (39\%) and community-based management ( } 59 \% \text {, but unstable and } \\
\text { insecure tenure of forests by frequent changes in policies) }\end{array}$ & $\begin{array}{l}\text { Baohua (2006); Zackey (2007); Brandt } \\
\text { et al. (2017) }\end{array}$ \\
\hline India & 1.4 & Government (35\%, area), community managed (38\%, area), and private ownership (14\%) & Brandt et al. (2017) \\
\hline Myanmar & 1.7 & $\begin{array}{l}\text { Centralized, managed by the national government with weak policies and unstable tenure } \\
\text { regimes }\end{array}$ & $\begin{array}{l}\text { Lin (2005); Woods (2015); Brandt et al. } \\
\text { (2017) }\end{array}$ \\
\hline Study area & 1 & $\begin{array}{l}\text { Conifer forests owned and managed by the government, oak scrub forests by communities, with } \\
\text { weak policies and law enforcement }\end{array}$ & Current study \\
\hline
\end{tabular}

Source: Brandt et al. (2017); DFR, annual rate of deforestation.

Furthermore, the sub-tropical oak scrub forests and sub-tropical broadleaved forests belong to local communities, managed under traditional management. The community-based management in this forest resembles Nepal's forest management regimes up to some extent but lacks a high level of monitoring, law enforcement, and management capabilities. Furthermore, the imposition of the logging ban policy in 1993 shifted the pattern of forest land conversion. Before the ban, deforestation was mainly in the sub-alpine and temperate forests. However, during the post-ban period, deforestation shifted to sub-tropical forests, most likely for fuel wood, livestock grazing, and shifting cultivation attributed to population increase. Similarly, in protected forests, the partial protection of forests attributed to weak law enforcement, insufficient monitoring, and community exclusion encourages the timber mafia for illegal harvesting (Ahmad et al., 2018; Zeb, 2019).

In summary, the present results pinpoint that, despite various conservation measures such as the Sarhad provincial conservation strategy (1996), KP forest ordinance (2002), and their Community Participation Rules, 2004, and most recently, the BTTAP (Billion Tree Tsunami Afforestation Project, 2014-15), the high rate of deforestation is reflecting the noneffectiveness of existing forest management regimes and their logging ban policy. Furthermore, the government of Pakistan recently launchpad a Ten Billion Tree Tsunami Program (TBTTP, 2019) throughout the country to improve and enhance forest cover. To achieve the goals of the TBTTP, the existing forest management regimes need major amendment. In this regard, we suggest adopting Nepal and Bhutan's management regime models with local participation in forest management and decision-making supported by high-level effective monitoring and law enforcement. Although the concept of joint forest management was introduced in 2004, however, inconsistent policies, lack of quality governance and monitoring, and unstable land rights and responsibilities are the major causes of their non-effectiveness. In the absence of partial or incomplete power transfer, decentralization may lead to unexpected outcomes (Ribot et al., 2006). Additionally, establishing protected areas (PAs) might help control deforestation globally, as countries with larger PAs had lower deforestation rates (Brandt et al., 2017).

\section{CONCLUSION AND RECOMMENDATIONS}

The results suggest that, under existing forest management regimes and their associated ban policy, the rate of deforestation has increased since the ban was imposed. Institutional neglect, weak law enforcement, and policy implementation, the conflicts between government and local on ownership rights through bureaucratic interference, unstable land tenure rights, lack of protected areas, and exclusion of conservation and community-based management are the major factors of non-effectiveness of the forest management regimes in the area. Therefore, we suggest the inclusion of conservation and community-based management, increasing managerial skills of local people, stable and secure rights, and high-rank monitoring and law enforcement into the existing management regimes. Furthermore, protected areas can potentially reduce deforestation and improve carbon-diversity; therefore, establishing more protected areas in the regions will be an effective strategy for forest carbon and diversity conservation.

\section{DATA AVAILABILITY STATEMENT}

The raw data supporting the conclusion of this article will be made available by the authors, without undue reservation.

\section{AUTHOR CONTRIBUTIONS}

$\mathrm{AA}$ and SA conceptualized the research idea, performed the methodology and analysis, and wrote the original draft. GN critically revised the manuscript and edited the paper. Q-JL supervised the work. NI was involved in GIS and remote sensing analysis and image preparation. XL was involved in funding acquisition.

\section{ACKNOWLEDGMENTS}

We are thankful to the Ministry of Science and Technology of the People's Republic of China (Research and Application of Key Techniques on Endangered Species Conservation and Prediction of Forest Fire and Pests in Response to Climate Change; 2013BAC09B00) for supporting this study. 


\section{REFERENCES}

Ahmad, A., Liu, Q.-J., Nizami, S. M., Mannan, A., and Saeed, S. (2018). Carbon Emission from Deforestation, forest Degradation and wood Harvest in the Temperate Region of Hindukush Himalaya, Pakistan between 1994 and 2016. Land Use Policy 78, 781-790. doi:10.1016/j.landusepol.2018.07.009

Ahmad, A., and Nizami, S. M. (2015). Carbon Stocks of Different Land Uses in the Kumrat valley, Hindu Kush Region of Pakistan. J. For. Res. 26, 57-64. doi:10. 1007/s11676-014-0008-6

Alix-Garcia, J., Janvry, A. d., and Sadoulet, E. (2005). A Tale of Two Communities: Explaining Deforestation in Mexico. World Dev. 33 (2), 219-235. doi:10.1016/j. worlddev.2004.07.010

Angelsen, A., Brockhaus, M., Sunderlin, W. D., and Verchot, L. V. (2012). Analysing REDD+: Challenges and Choices. Cifor.

Angelsen, A. (2010). Policies for Reduced Deforestation and Their Impact on Agricultural Production, Proc. Natl. Acad. Sci. 107, 19639-19644.

Baohua, Z. (2006). "Changes and Trends in forest Tenure and Institutional Arrangements for Collective forest Resources in Yunnan provinceForestry Policy and Institutional Working Paper" in 2006: Understanding forest Tenure in South and Southeast Asia (China: FAO).

Bare, M., Kauffman, C., and Miller, D. C. (2015). Assessing the Impact of International Conservation Aid on Deforestation in Sub-saharan Africa. Environ. Res. Lett. 10 (12), 125010. doi:10.1088/1748-9326/10/12/125010

Bertzky, B., Corrigan, C., Kemsey, J., Kenney, S., Ravilious, C., Besançon, C., et al. (2012). "Protected Planet Report 2012: Tracking Progress towards Global Targets for Protected Areas," in Protected Planet Report 2012: Tracking Progress towards Global Targets for Protected Areas.

Bhattarai, M., and Hammig, M. (2004). Governance, Economic Policy, and the Environmental Kuznets Curve for Natural Tropical Forests. Envir. Dev. Econ. 9, 367-382. doi:10.1017/s1355770x03001293

Brandt, J. S., Allendorf, T., Radeloff, V., and Brooks, J. (2017). Effects of National forest-management Regimes on Unprotected Forests of the Himalaya. Conservation Biol. 31, 1271-1282. doi:10.1111/cobi.12927

Brown, C., Durst, P. B., and Enters, T. (2001). "Forests Out of Bounds: Impacts and Effectiveness of Logging Bans in Natural Forests in Asia-Pacific," in Executive Summary.

Bugayong, L. A. (2006). "Effectiveness of Logging Ban Policies in Protecting the Remaining Natural Forests of the Philippines," in Proceedings of the 2006 Berlin Conference on Human Dimensions of Global Environmental Change-Resource Policies: Effectiveness Efficiency, and Equity. Berlin, Germany. Freie University. Paper presented at the.

Canadell, J. G., and Raupach, M. R. (2008). Managing Forests for Climate Change Mitigation. Science 320 (5882), 1456-1457. doi:10.1126/science.1155458

CCF (2011). Office of the Chief Conservator of Forest. Peshawar, Pakistan: Khyber Pakhtunkhwa.

DeFries, R. S., Rudel, T., Uriarte, M., and Hansen, M. (2010). Deforestation Driven by Urban Population Growth and Agricultural Trade in the Twenty-First century. Nat. Geosci 3, 178-181. doi:10.1038/ngeo756

Elsen, P. R., Monahan, W. B., and Merenlender, A. M. (2018). Global Patterns of protection of Elevational Gradients in Mountain Ranges. Proc. Natl. Acad. Sci. USA 115 (23), 6004-6009. doi:10.1073/pnas.1720141115

FAO (2011). Global Forest Resources Assessment 2000. Rome, Italy: Food and Agriculture Organization of the United Nations.

FAO (2015). Global Forest Resources Assessment.FAO Forestry Paper No. $1 /$. Rome: UN Food and Agriculture Organization.

Fischer and project (2010). Study on Timber Harvesting Ban in NWFP. Pakistan: Intercooperation Pakistan.

Geist, H. J., and Lambin, E. F. (2001). What Drives Tropical Deforestation. LUCC Rep. Ser. 4116.

Hansen, M., Potapov, P., Moore, R., Hancher, M., Turubanova, S., Tyukavina, A., et al. (2013). Hansen/UMD/Google/USGS/NASA Tree Cover Loss and Gain Area. University of MarylandGlobal Forest Watch on March7. Google, USGS, and NASA.Accessed through2015.

Hosonuma, N., Herold, M., de Sy, V., de Fries, R. S., Brockhaus, M., Verchot, L., et al. (2012).An Assessment of Deforestation and forest Degradation Drivers in Developing Countries. doi:10.1088/1748-9326/7/4/044009
IUCN (2020). Pakistan's 'Protected Areas Initiative.

Keenan, R. J., Reams, G. A., Achard, F., de Freitas, J. V., Grainger, A., and Lindquist, E. (2015). Dynamics of Global forest Area: Results from the FAO Global Forest Resources Assessment 2015. For. Ecol. Manage. 352, 9-20. doi:10.1016/j.foreco. 2015.06.014

Khan, S. (2004). Forestry Statistics of Pakistan. Pakistan Forest Institute.

KPBS (2020). Bureau of Statistics Khyber Pakhtunkhwa. Pakistan.

Lambin, E. F., and Geist, H. J. (2008). Land-use and Land-Cover Change: Local Processes and Global Impacts. Springer Science \& Business Media.

Lambin, E. F., and Meyfroidt, P. (2010). Land Use Transitions: Socio-Ecological Feedback versus Socio-Economic Change. Land Use Policy 27, 108-118. doi:10. 1016/j.landusepol.2009.09.003

Lin, H. (2005). Community Forestry Initiatives in Myanmar: an Analysis from a Social Perspective. Int. Forest. Rev. 7, 27-36. doi:10.1505/ifor.7.1.27.64154

Mannan, A. (2001). Resource Management Plan for Warrai Forests of Dir Forest division 2001-2015.

Mannan, A., Liu, J., Zhongke, F., Khan, T. U., Saeed, S., Mukete, B., et al. (2019). Application of Land-Use/land Cover Changes in Monitoring and Projecting forest Biomass Carbon Loss in Pakistan. Glob. Ecol. Conservation 17, e00535. doi:10.1016/j.gecco.2019.e00535

Mannan, A. (2009). "Operational Plan for the Protected Forests of Chitral forest Division K. P. F. Department," in Forestry Planning and Monitoring circle Peshwar (Pakistan.

Mannan, A. (2002). Working Plan for. For Dir Uncontrolled Forests of Dir Forest division 2001-2015.

Mannan, A., Zhongke, F., Ahmad, A., Liu, J., Saeed, S., and Mukete, B. (2018). Carbon Dynamic Shifts with Land Use Change in Margallah Hills National Park, Islamabad (Pakistan) from 1990 to 2017. Appl. Ecol. Env. Res. 16, 3197-3214. doi:10.15666/aeer/1603_31973214

MCC (2015). National Forest Policy. Govt of Pakistan: Ministry of Climate Change.

Muhammad, Y. K. (2000). Resource Management Plan for Alpuri Forest Division (2000-2015).

Ojha, H., Persha, L., and Chhatre, A. (2009). Community Forestry in Nepal: a Policy Innovation for Local Livelihoods. Proven Successes Agric. Dev. 123.

Palmer, C., and Engel, S. (2009). Avoided Deforestation: Prospects for Mitigating Climate Change. Routledge.

PBS (2017). Statistics Division of the Government of Pakistan. Islamabad.

Puyravaud, J.-P. (2003). Standardizing the Calculation of the Annual Rate of Deforestation. For. Ecol. Manage. 177, 593-596. doi:10.1016/s0378-1127(02) 00335-3

Qamer, F. M., Abbas, S., Saleem, R., Shehzad, K., Ali, H., and Gilani, H. (2012). Forest Cover Change Assessment in Conflict-Affected Areas of Northwest Pakistan: The Case of Swat and Shangla Districts. J. Mt. Sci. 9, 297-306. doi:10. 1007/s11629-009-2319-1

Qamer, F., Shehzad, K., Abbas, S., Murthy, M., Xi, C., Gilani, H., et al. (2016). Mapping Deforestation and Forest Degradation Patterns in Western Himalaya, Pakistan. Remote Sensing 8 385. doi:10.3390/rs8050385

Qasim, M., Hubacek, K., Termansen, M., and Khan, A. (2011). Spatial and Temporal Dynamics of Land Use Pattern in District Swat, Hindu Kush Himalayan Region of Pakistan. Appl. Geogr. 31, 820-828. doi:10.1016/j. apgeog.2010.08.008

Ribot, J. C., Agrawal, A., and Larson, A. M. (2006). Recentralizing while Decentralizing: How National Governments Reappropriate forest Resources. World Dev. 34 (11), 1864-1886. doi:10.1016/j.worlddev.2005.11.020

Saddozi, A. Q. K. (1995). Revised Working Plan for Dir Kohistan Forest of Dir Forest Division (1995-2015).

Sarker, S. K., Deb, J. C., and Halim, M. A. (2011). A Diagnosis of Existing Logging Bans in Bangladesh. Int. For. Rev. 13 (4), 461-475. doi:10.1505/ 146554811798811344

Sikor, T., Auld, G., Bebbington, A. J., Benjaminsen, T. A., Gentry, B. S., Hunsberger, C., et al. (2013). Global Land Governance: from Territory to Flow? Curr. Opin. Environ. Sustainability 5 (5), 522-527. doi:10.1016/j.cosust.2013.06.006

Tan, N. Q. (2006). "Trends in forest Ownership, forest Resources Tenure and Institutional Arrangements: Are They Contributing to Better forest Management and Poverty Reduction? Case Study from Vietnam," in Understanding Forest Tenure in South and Southeast Asia-Forestry Policy and Institutions, 355-407. 
Tuynh, V. H., and Phuong, P. X. (2001). Impacts and Effectiveness of Logging Bans in Natural Forests.

Ullah, S., Farooq, M., Shafique, M., Siyab, M. A., Kareem, F., and Dees, M. (2016). Spatial Assessment of forest Cover and Land-Use Changes in the Hindu-Kush Mountain Ranges of Northern Pakistan. J. Mt. Sci. 13 (7), 1229-1237. doi:10. 1007/s11629-015-3456-3

Usman, G. (2017). Working Plan for Sawt Forest Division (2017-2027).

Wani, B. A., Shah, H., and Khan, S. (2004). Forestry Statistics of Pakistan. Pakistan Forest Institute.

Warman, R. D., and Nelson, R. A. (2016). Forest Conservation, wood Production Intensification and Leakage: An Australian Case. Land use policy 52, 353-362. doi:10.1016/j.landusepol.2015.12.020

Woods, K. (2015). Commercial Agriculture Expansion in Myanmar: Links to Deforestation, Conversion Timber, and Land Conflicts. For. Trends.

Yang, B., Busch, J., Zhang, L., Ran, J., Gu, X., Zhang, W., et al. (2015). China's Collective forest Tenure Reform and the Future of the Giant Panda. Conservation Lett. 8 (4), 251-261. doi:10.1111/conl.12143

Yusuf, M. (2009). Legal and Institutional Dynamics of forest Management in Pakistan. Mcgill Int'l J. Sust.Dev. L. \&Pol'y 5, 45.

Zackey, J. (2007). Peasant Perspectives on Deforestation in Southwest China. Mountain Res. Dev. 27, 153-161. doi:10.1659/mrd.0837
Zeb, A. (2019). Spatial and Temporal Trends of forest Cover as a Response to Policy Interventions in the District Chitral, Pakistan, Appl. Geogr., 102, 39-46. doi:10.1016/j.apgeog.2018.12.002

Conflict of Interest: The authors declare that the research was conducted in the absence of any commercial or financial relationships that could be construed as a potential conflict of interest.

Publisher's Note: All claims expressed in this article are solely those of the authors and do not necessarily represent those of their affiliated organizations, or those of the publisher, the editors, and the reviewers. Any product that may be evaluated in this article, or claim that may be made by its manufacturer, is not guaranteed or endorsed by the publisher.

Copyright $\odot 2022$ Ahmad, Ahmad, Nabi, Liu, Islam and Luan. This is an openaccess article distributed under the terms of the Creative Commons Attribution License (CC BY). The use, distribution or reproduction in other forums is permitted, provided the original author(s) and the copyright owner(s) are credited and that the original publication in this journal is cited, in accordance with accepted academic practice. No use, distribution or reproduction is permitted which does not comply with these terms. 